\title{
DEKONSTRUKSI KONSEP GOOD UNIVERSITY GOVERNANCE DALAM PELAKSANAAN ANGGARAN PERGURUAN TINGGI NEGERI BADAN HUKUM
}

\author{
Lussiana $^{1}$, Titik Mildawati ${ }^{2}$, dan Fidiana ${ }^{3}$ \\ Sekolah Tinggi Ilmu Ekonomi Indonesia, Surabaya ${ }^{1,2,3}$ \\ lussiana.hm@gmail.com ${ }^{1}$
}

\begin{abstract}
This study aims to deconstruct the concept of Good University Governance in the implementation of the budget of Legal Entity State Universities (PTN-BH). Therefore an approach is needed that can expose the concept of Good University Governance in a budget implementation. This research is conceptual research. Researchers are motivated to formulate the concept because they see that the budget in an institution has an important role in determining the results of organizational performance. Legal Entity State Universities are required to compile organizational performance reports in accordance with Menristek Dikti Regulation Number 40 of 2016. Indicators of organizational performance assessment for PTN-BH based on Menristek Dikti Regulation Number 40 of 2016 are must meet Good University Governance which consists of transparency, accountability, responsibility, effective and efficient. The success of the PTN-BH budget implementation is in fact measured by the fulfillment of Good University Governance. Therefore it is necessary to first understand the concept of Good University Governance in implementing the PTN-BH budget. This study uses contextual concepts by understanding existing theories and relating them to existing reality / daily life.
\end{abstract}

Keywords : Good University Governance, Budget, Performance, Legal Entity State University

\begin{abstract}
ABSTRAK
Penelitian ini bertujuan untuk men-dekonstruksi konsep Good University Governance dalam pelaksanaan anggaran Perguruan Tinggi Negeri Badan Hukum (PTN-BH). Oleh karena itu diperlukan sebuah pendekatan yang dapat mengekspose konsep Good University Governance dalam sebuah pelaksanaan anggaran. Penelitian ini merupakan penelitian konseptual. Peneliti termotivasi merumuskan konsep tersebut karena melihat bahwa anggaran dalam sebuah institusi memiliki peran penting dalam menetukan hasil kinerja organisasinya. Perguruan Tinggi Negeri Badan Hukum dituntut untuk menyusun laporan kinerja organisasi sesuai dengan Peraturan Menristek Dikti Nomor 40 Tahun 2016. Indikator penilaian kinerja organisasi bagi PTN-BH berdasarkan Peraturan Menristek Dikti Nomor 40 Tahun 2016 adalah harus memenuhi Good University Governance yang terdiri dari transparansi, akuntabilitas, responsibilitas, efektif dan efisien. Keberhasilan pelaksanaan anggaran PTN-BH nyatanya kini diukur melalui terpenuhinya Good University Governance. Oleh karena itu perlu dipahami terlebih dahulu konsep Good University Governance dalam pelaksanaan anggaran PTN-BH. Penelitian ini menggunakan konsep kontekstual dengan memahami teori yang ada dan mengaitkannya dengan realita yang ada/kehidupan sehari-hari.
\end{abstract}

Kata kunci : Good University Governance, Anggaran, Kinerja, PTN Badan Hukum 
Lussiana, Titik Mildawati dan Fidiana

Dekonstruksi Konsep Good University Governance Dalam Pelaksanaan Anggaran Perguruan Tinggi

Negeri Badan Hukum

\section{PENDAHULUAN}

Perguruan Tinggi Negeri (PTN) merupakan salah satu lembaga sosial yang bertugas mengembangkan ilmu pengetahuan dan teknologi. Pemerintah membuka kemungkinan secara selektif kepada Perguruan Tinggi Negeri yang dinilai sudah memiliki kemampuan pengelolaan yang mencukupi untuk dapat memiliki kemandirian, otonomi dan tanggung jawab yang lebih besar untuk diubah status hukumnya menjadi Badan Hukum Milik Negara (BHMN) yang dapat berperan sebagai kekuatan moral dalam proses pembangunan masyarakat madani yang lebih demokratis dan mampu bersaing secara global. Anggaran merupakan komponen penting dalam sebuah organisasi, baik organisasi sektor swasta maupun organisasi sektor publik . Menurut (Hansen dan Mowen, 2004) kelebihan dari sistem anggaran diantaranya anggaran mendorong para manajer untuk mengembangkan arahan umum bagi organisasi, mengantisipasi masalah, dan mengembangkan kebijakan untuk masa depan. Kelebihan lain adalah anggaran dapat memperbaiki pembuatan keputusan selaian itu anggaran juga merupakan rencana tindakan-tindakan pada masa yang akan datang untuk mencapai tujuan organisasi. Pelaksanaan anggaran yang baik dapat mendorong keterbukaan informasi dan kecepatan serta ketepatan dalam pengambilan keputusan sehingga harapan peningkatan kinerja organisasi dapat tercapai.

Kinerja suatu organisasi dinilai baik jika organisasi yang bersangkutan mampu melaksankan tugas-tugas dalam rangka mencapai visi, misi dan tujuan yang telah ditetapkan pada standar yang tinggi dengan biaya yang rendah. Secara teknis kinerja yang baik bagi suatu organisasi dapat tercapai ketika pelaksanaan anggaran yang dilakukan oleh organisasi yang bersangkutan dapat mengimplementasikan Good University Governance melalui tercapaianya akuntabilitas, transparansi, efisien, efektifitas, dan responsibilitas. Penentuan pengukuran kinerja melalui Good University Governance dengan transparansi, akuntabilitas, responsibilitas, efektif dan efisien sebagai indikator pengukurannya sesuai dengan pemenuhan laporan kinerja organisasi berdasarkan Peraturan Menteri Ristek Dikti Nomor 40 Tahun 2016 yang mengatur mengenai kewajiban untuk menyusun Laporan Kinerja Organisasi bagi PTN Badan Hukum.

Secara sederhana, good university governance dapat kita pandang sebagai penerapan prinsip-prinsip dasar konsep "good governance" dalam sistem dan proses governance pada institusi perguruan tinggi, melalui berbagai penyesuaian yang dilakukan berdasarkan nilai-nilai yang harus dijunjung tinggi dalam penyelenggaraan perguruan tinggi secara khusus dan umum. Selain itu juga berbasis pada tujuan pengembangan pendidikan dan keilmuan akademik, pengembangan manusia seutuhnya, sedangkan yang lain ditempatkan sebagai alat atau means, bukan tujuan dasar. Transparansi di bidang pengelolaan berarti adanya keterbukaan dalam mengelola suatu kegiatan. Akuntabilitas merupakan prinsip yang menjamin bahwa setiap kegiatan penyelenggaraan pemerintahan dapat dipertanggungjawabkan secara terbuka oleh pelaku kepada pihak-pihak yang terkena dampak penerapan kebijakan. Responsibilitas (responsibility) merupakan konsep yang berkenaan dengan standar profesional dan kompetensi teknis yang dimiliki administrator (birokrasi publik) dalam menjalankan tugasnya. Efisiensi adalah perbandingan antara output dengan input dimana ukuran efisien dapat dikembangkan dengan menghubungkan antara biaya yang sesungguhnya dengan biaya standar yang 
Lussiana, Titik Mildawati dan Fidiana

Dekonstruksi Konsep Good University Governance Dalam Pelaksanaan Anggaran Perguruan Tinggi

Negeri Badan Hukum

telah ditetapkan sebelumnya. Dikatakan efisien jika suatu produk atau hasil kerja dapat dicapai dengan dana yang serendah-rendahnya.

Tujuan dari artikel ini adalah untuk memahami bagaimana konsep good university governance dalam pelaksanaan anggaran Perguruan Tinggi Negeri Badan Hukum (PTN$\mathrm{BH})$. Penelitian ini diharapkan dapat memberikan beberapa manfaat diantaranya adalah terkait anggaran organisasi sektor publik, peran Good University Governance dalam meningkatkan kinerja Perguruan Tinggi Negeri Badan Hukum. Kemudian dapat memberikan masukan bagi pihak Kemristek Dikti dalam pengambilan keputusan terkait implementasi Permenristek Dikti No. 40 Tahun 2016. Terakhir dapat membantu tim manajemen PTN Badan Hukum untuk mengetahui peran Good University Governance bagi mereka.

\section{LANDASAN TEORI}

\section{Good Corporate Governance}

Secara istilah, definisi GCG menurut Syakhroza dan Akhmad (2008) adalah suatu mekanisme tata kelola organisasi secara baik dalam melakukan pengelolaan sumber daya organisasi secara efisien, efektif, ekonomis ataupun produktif dengan prinsip-prinsip keterbukaan, akuntabilitas, pertanggungjawaban, independen, dan adil dalam rangka mencapai tujuan organisasi. Selain itu Daniri (2014) mengungkapkan bahwa good corporate governance merupakan struktur dan proses (peraturan, sistem dan prosedur) untuk memastikan prinsip tarif bermigrasi menjadi kultur, mengarahkan dan mengendalikan perusahaan untuk mewujudkan pertumbuhan berkelanjutan, meningkatkan nilai tambah dengan tetap memperhatikan keseimbangan kepentingan stakehorders yang sesuai dengan prinsip korporasi yang sehat dan peraturan perundangundangan yang berlaku.

\section{Good University Governance}

University governance didefinisikan sebagai bentuk dan proses konstitusional ketika universitas mengatur urusannya sendiri (Shattock, 2006). Governance adalah cara dimana kekuasaan atau otoritas digunakan organisasi dalam mengalokasikan dan mengelola sumberdaya. Governance melibatkan kebijakan dan prosedur untuk pengambilan keputusan dan pengendalian atas pengarahan dan pengelolaan organisasi agar efektif (Carnagie, 2009). Hal tersebut mengacu kepada praktik yang mengharuskan adanya pengawasan, pengendalian, pengungkapan, dan transparansi (Harris and Cunningham, 2009), struktur universitas, delegasi dan pengambilan keputusan, perencanaan, koherensi organisasi dan pengarahan (Considine, 2004). PTN sebagai sebagai pusat pengembangan ilmu dan teknologi diharapkan mampu meningkatkan peranannya dalam memajukan dan mempercepat pembangunan nasional (Sukirman dan Maylina, 2012). PTN diharapkan menjadi sebuah komunitas yang mampu melindungi dirinya dari pengaruh nilai-nilai lingkungan eksternal yang mungkin korup atau mengandung keburukan. Independensi diperlukan untuk mendukung terwujudnya inovasi atau perkembangan pemikiran dan ilmu pengetahuan (Anwar dan Partolo, 2012). 
Lussiana, Titik Mildawati dan Fidiana

Dekonstruksi Konsep Good University Governance Dalam Pelaksanaan Anggaran Perguruan Tinggi

Negeri Badan Hukum

Kinerja suatu organisasi dinilai baik jika organisasi yang bersangkutan mampu melaksankan tugas-tugas dalam rangka mencapai visi, misi dan tujuan yang telah ditetapkan pada standar yang tinggi dengan biaya yang rendah. Secara teknis kinerja yang baik bagi suatu organisasi dapat tercapai ketika kinerja anggaran organisasi yang bersangkutan telah memenuhi fungsi anggaran sektor public dan dapat mengimplementasikan Good University Governance melalui tercapaianya akuntabilitas, transparansi, efisien, efektifitas, dan responsibilitas. Hal ini sebagaimana diungkapkan oleh (Mardiasmo, 2009)bahwa anggaran merupakan perilaku manusia dalam rangka mencapai tujuan keuangan. Namun bagi sektor publik seperti pemerintah, anggaran tidak hanya rencana tahunan tetapi juga merupakan bentuk akuntabilitas atas pengelolaan dana publik yang dibebankan kepadanya.

\section{Anggaran}

Anggaran merupakan alat untuk merencanakan dan mengendalikan keuangan perusahaan dalam penyusunannya dilakukan secara periodik. Sedangkan (Rudianto, 2009)menyatakan bahwa anggaran adalah rencana kerja organisasi di masa mendatang yang diwujudkan dalam bentuk kuantitatif, formal, dan sistematis. Dari pengertian di atas maka penulis menyimpulkan bahwa pengertian anggaran adalah suatu rencana yang terperinci dan sistematis serta meliputi seluruh kegiatan dalam organisasi maupun instansi pemerintah yang dinyatakan dalam satuan moneter dan rencana masa depan dalam jangka waktu tertentu dan disusun secara formal.

\section{Anggaran Sektor Publik}

Menurut (Mardiasmo, 2009)anggaran sektor publik merupakan alat perencanaan manajemen untuk mencapai tujuan organisasi. Anggaran sektor publik dibuat untuk merencanakan tindakan apa yang akan dilakukan oleh pemerintah, berapa biaya yang dibutuhkan, dan berapa hasil yang diperoleh dari belanja pemerintah tersebut.

\section{Anggaran Berbasis Kinerja}

Pengertian anggaran berbasis kinerja menurut (Anggarini, 2010) adalah anggaran berbasis kinerja merupakan sistem perencanaan, penganggaran dan evaluasi yang menekankan pada keterkaitan antara anggaran dengan hasil yang diinginkan. Penerapan anggaran berbasis kinerja harus dimulai dengan perencanaan kinerja, baik pada level nasional (pemerintah) maupun level instansi (kementerian/lembaga), yang berisi komitmen tentang kinerja yang akan dihasilkan, yang dijabarkan dalam programprogram dan kegiatan-kegiatan yang akan dilakukan.

Selain itu (Halim, 2012) menjelaskan bahwa anggaran berbasis kinerja merupakan penganggaran bagi manajemen untuk mengaitkan setiap pendanaan yang dituangkan dalam kegiatankegiatan dengan keluaran dan hasil yang diharapkan termasuk efisiensi dalam pencapaian hasil dari keluaran tersebut. Keluaran dan hasil tersebut dituangkan dalam target kinerja pada setiap unit kerja.

\section{METODE PENELITIAN}

Pendekatan yang digunakan dalam penelitian ini adalah menggunakan pendekatan kontekstual. Dimana dalam penelitian ini akan dibahas terlebih dahulu teori Good 
Lussiana, Titik Mildawati dan Fidiana

Dekonstruksi Konsep Good University Governance Dalam Pelaksanaan Anggaran Perguruan Tinggi

Negeri Badan Hukum

University Governanance dan teori anggaran sektor publik dan selanjutnya penjelasan teori tersebut akan dilanjutkan dengan pelaksanaan atau penerapan dalam realita pada beberapa Perguruan Tinggi Negeri Badan Hukum di Indonesia.

\section{HASIL PENELITIAN DAN PEMBAHASAN Konsep Good Governance}

Konsep good governance dapat diartikan menjadi acuan untuk proses dan struktur hubungan politik dan sosial ekonomi yang baik. Human interest adalah faktor terkuat yang saat ini mempengaruhi baik buruknya dan tercapai atau tidaknya sebuah negara serta pemerintahan yang baik. Sudah menjadi bagian hidup yang tidak bisa dipisahkan bahwa setiap manusia memiliki kepentingan. Baik kepentingan individu, kelompok, atau kepentingan masyarakat nasional bahkan internasional. Dalam rangka mewujudkan setiap kepentingan tersebut selalu terjadi benturan. Begitu juga dalam merealisasikan apa yang namanya "good governance" benturan kepentingan selalu lawan utama. Kepentingan melahirkan jarak dan sekat antar individu dan kelompok yang membuat sulit tercapainya kata "sepakat".

Konsep Good Governance sebenarnya telah lama dilaksanakan oleh semua pihak yaitu Pemerintah, Swasta dan Masyarakat, namun demikian masih banyak yang rancu memahami konsep Governance. Secara sederhana, banyak pihak menerjemahkan governance sebagai Tata Pemerintahan. Tata pemerintahan disini bukan hanya dalam pengertian struktur dan manajemen lembaga yang disebut eksekutif, karena pemerintah (government) hanyalah salah satu dari tiga aktor besar yang membentuk lembaga yang disebut governance. Dua aktor lain adalah private sektor (sektor swasta) dan civil society (masyarakat madani). Karenanya memahami governance adalah memahami bagaimana integrasi peran antara pemerintah (birokrasi), sektor swasta dan civil society dalam suatu aturan main yang disepakati bersama. Lembaga pemerintah harus mampu menciptakan lingkungan ekonomi, politik, sosial budaya, hukum dan keamanan yang kondusif. Sektor swasta berperan aktif dalam menumbuhkan kegiatan perekonomian yang akan memperluas lapangan kerja dan meningkatkan pendapatan, sedangkan civil society harus mampu berinteraksi secara aktif dengan berbagai macam aktifitas perekonomian, sosial dan politik termasuk bagaimana melakukan kontrol terhadap jalannya aktifitas-aktifitas tersebut.

Dalam konsep ini, lembaga pemerintahan berperan memberikan pelayanan demi kesejahteraan rakyat dengan sistem peradilan yang baik dan sistem pemerintahan yang dapat dipertanggungjawaban kepada publik. Kunci utama memahami good governance adalah pemahaman atas prinsip-prinsip di dalamnya. Bertolak dari prinsip-prinsip ini akan didapatkan tolak ukur kinerja suatu pemerintahan. Baik-buruknya pemerintahan bisa dinilai bila ia telah bersinggungan dengan semua unsur prinsip-prinsip good governance.

\section{Konsep Good University Governance}

University governance didefinisikan sebagai bentuk dan proses konstitusional ketika universitas mengatur urusannya sendiri (Shattock, 2006). Governance adalah cara dimana kekuasaan atau otoritas digunakan organisasi dalam mengalokasikan dan 
Lussiana, Titik Mildawati dan Fidiana

Dekonstruksi Konsep Good University Governance Dalam Pelaksanaan Anggaran Perguruan Tinggi

Negeri Badan Hukum

mengelola sumberdaya. Governance melibatkan kebijakan dan prosedur untuk pengambilan keputusan dan pengendalian atas pengarahan dan pengelolaan organisasi agar efektif (Carnagie, 2009). Hal tersebut mengacu kepada praktik yang mengharuskan adanya pengawasan, pengendalian, pengungkapan, dan transparansi (Harris, J., 2009), struktur universitas, delegasi dan pengambilan keputusan, perencanaan, koherensi organisasi dan pengarahan (Considine, 2004). PTN sebagai sebagai pusat pengembangan ilmu dan teknologi diharapkan mampu meningkatkan peranannya dalam memajukan dan mempercepat pembangunan nasional (Sukirman dan Maylina, 2012). PTN diharapkan menjadi sebuah komunitas yang mampu melindungi dirinya dari pengaruh nilai-nilai lingkungan eksternal yang mungkin korup atau mengandung keburukan. Independensi diperlukan untuk mendukung terwujudnya inovasi atau perkembangan pemikiran dan ilmu pengetahuan (Anwar dan Partolo, 2012). Pendidikan tinggi dituntut untuk lebih menyeimbangkan peranannya sebagai pusat intelektual sekaligus menjaga agar tetap relevan dengan kondisi sosial di sekitarnya dalam menghadapi transformasi ekonomi, teknologi dan kondisi sosial yang sangat cepat (Indrajit dan Djokopranoto, 2006). Institusi PTN memiliki keistimewaan dibandingkan institusi lain yang terletak pada fungsi dasarnya yaitu dalam hal pendidikan, pengajaran, dan usaha penemuan atau inovasi (riset) atau dikenal sebagai Tri Dharma PT. Fungsi-fungsi inilah yang kemudian mendefinisikan peran PTN dalam masyarakat (Sukirman dan Maylina, 2012).

Dengan dasar fungsi dan peran Tri Dharma PTN itulah maka pengelolaan sebuah institusi PT tidak mungkin disamakan dengan pengelolaan sebuah negara maupun korporasi. Ada koridor-koridor tertentu yang berkaitan dengan nilai-nilai luhur (values), baik dalam hal akademik maupun social values yang harus dijaga didalamnya. Hal-hal lain dalam penyelenggaraan PTN harus ditempatkan sebagai alat untuk mendukung pencapaian tujuan dasar tersebut(Anwar dan Partolo, 2012). Inilah yang menjadi dasar munculnya wacana GUG dalam penyelenggaraan sebuah institusi PTN. Dengan demikian secara sederhana GUG dapat dipandang sebagai penerapan prinsip-prinsip dasar konsep "good governance" dalam sistem dan proses governance pada institusi PT, melalui berbagai penyesuaian berdasarkan nilai-nilai yang harus dijunjung tinggi dalam penyelenggaraan PT (Wijatno, 2009). Governance of Irish Universities (2007) menjelaskan GUG sebagai berikut:

"A robust system of governance is vital in order to enable organizations to operate effectively and to discharge their responsibilities as regards transparency and accountability to those they serve. Given their pivotal role in society and in national economic and social development, as well as their heavy reliance on public as well as private funding, good governance is particularly important in the case of the universities (HEA-IUA, 2007; page.3)"

Dalam implementasinya, prinsip-prinsip atau karakteristik dasar dari good governance masih relevan untuk diterapkan dalam konsep good university governance. Dalam penyelenggaraannya, sebuah institusi perguruan tinggi harus memenuhi prinsipprinsip partisipasi, orientasi pada konsensus, akuntabilitas, transparansi, responsif, efektif dan efisien, ekuiti (persamaan derajat) dan inklusifitas, dan penegakan/supremasi hukum, namun yang berbeda adalah nilai dan tujuan yang menjiwainya. Prinsip-prinsip 
Lussiana, Titik Mildawati dan Fidiana

Dekonstruksi Konsep Good University Governance Dalam Pelaksanaan Anggaran Perguruan Tinggi

Negeri Badan Hukum

manajerial tersebut hendaknya diterapkan untuk mendukung fungsi-fungsi dan tujun dasar pendidikan tinggi. Selain itu, perbedaan lain adalah dalam hal stakeholders yang terkait dengan penyelenggaraan pendidikan dan perguruan tinggi.

Penerapan ini dapat berbeda-beda, disesuaikan dengan kondisi dan paham yang dianut oleh suatu bangsa atau masyarakat. Contohnya, good university governance di Amerika Serikat biasanya diterapkan dengan memberikan otonomi penuh, baik dalam hal akademik maupun manajerial dan pembiayaan, terhadap institusi perguruan tinggi selama masih dapat dipertanggungjawabkan. Konsekuensinya, pengaruh pemerintah relatif lemah dan sebaliknya, kewenangan manajer eksekutif dan dewan suatu perguruan tinggi menjadi kuat. Hal ini berbeda dengan sebagian besar negara-negara eropa, dimana good university governance diterapkan dengan pemberian otonomi dalam hal akademik tetapi tidak sepenuhnya dalam hal manajerial dan pembiayaan, sehingga pengaruh negara dalam hal manajerial menjadi cukup besar. Beberapa negara seperti Austria bahkan menanggung penuh biaya pendidikan tinggi sehingga mahasiswa suatu perguruan tinggi tidak perlu membayar biaya pendidikan. Sementara negara-negara Asia Tenggara umumnya masih mencari bentuk terbaik dan berkutat diantara kedua ekstrim tadi.

Nampaknya ada sebuah kesepahaman atau kesetujuan umum mengenai pentingnya otonomi dalam usaha pencapaian academic excellence (yaitu dalam hal pengajaran dan riset) untuk perguruan tinggi, akan tetapi hal yang sama belum berlaku dalam hal manajerial dan pembiayaan. Perbedaan pandangan ini biasanya terkait dengan pentingnya fungsi perguruan tinggi bagi masyarakat dan mahalnya biaya penyelenggaraan pendidikan tinggi. Kecenderungan saat ini, tingginya biaya pendidikan tinggi biasanya dianggap dapat membebani negara dan masyarakat, sehingga perguruan tinggi dianggap lebih baik berusaha mencari sumber-sumber pembiayaan mandiri.

\section{Konsep Good University Governance PTN Badan Hukum}

Setelah era reformasi tahun 1998 yang diikuti dengan diterimanya IMF sebagai lembaga donor di Indonesia, wacana good governance mulai mengemuka. Bersamaan dengan itu, cukup banyak persyaratan yang diajukan oleh IMF dalam menyalurkan pinjamannya, salah satunya adalah otonomi perguruan tinggi. Pemerintah kemudian menawarkan status Badan Hukum Milik Negara pada perguruan tinggi negeri di Indonesia yang dinilai sudah cukup siap untuk mengadopsi status tersebut. Tawaran yang diajukan mencakup otonomi yang lebih luas dalam hal penentuan kebijakan akademik bagi PTN-PTN tersebut. Otonomi akademik ini juga diikuti oleh otonomi manajerial dan pembiayaan.

Wacana good university governance sepertinya telah menjadi sebuah wacana umum yang cukup menarik untuk diadopsi dalam pencarian bentuk governance yang baik untuk PTN-PTN tersebut. Akan tetapi, ada beberapa hal yang perlu diperhatikan dalam penyelenggaraan good university governance ini, terutama dalam hal penerapan prinsipprinsip atau karakteristik dasarnya. Menurut (Andrianto, 2007) keterbukaan secara sungguh-sungguh, menyeluruh, dan memberi tempat bagi partisipasi aktif dari seluruh lapisan masyarakat dalam proses pengelolaan sumber daya publik. Sedangkan menurut (Wijatno, 2009) dalam mengukur transparansi pada pengelolaan perguruan tinggi harus dan dapat menerapkan prinsip keterbukaan di bidang keuangan, sistem dan prosedur 
Lussiana, Titik Mildawati dan Fidiana

Dekonstruksi Konsep Good University Governance Dalam Pelaksanaan Anggaran Perguruan Tinggi

Negeri Badan Hukum

penerimaan mahasiswa baru, sistem dan prosedur akuntansi, pelaporan keuangan, rekruitmen dosen dan karyawan, pemilihan pejabat struktural, pemilihan pengurus dan informasi-informasi penting lainnya kepada pemangku kepentingan secara memadai, akurat dan tepat waktu.

Transparansi atau keterbukaan merupakan sebuah prasyarat dasar untuk menunjang adanya partisipasi dan menjaga akuntabilitas institusi. Proses partisipasi memerlukan ketersediaan informasi yang memadai dan kemudahan bagi seluruh stakeholders dalam mengakses informasi tersebut. Selain itu, transparansi memungkinkan seluruh stakeholders untuk dapat mengawasi dan mengevaluasi kinerja institusi. Dalam hal anggaran atau keuangan, transparansi ini menjadi sangat urgen terutama dalam era BHMN, mengingat arus perputaran uang dalam institusi perguruan tinggi menjadi lebih besar dan kompleks. Akan tetapi, transparasi ini hendaknya tidak hanya dalam hal anggaran, melainkan seluruh dinamika yang terjadi dalam dinamika penyelenggaraan perguruan tinggi.

Perguruan Tinggi harus mempunyai uraian tugas dan tanggung jawab yang jelas (tertulis) dari pejabat struktural. Kriterian dan proses pengukuran kinerja, pengawasan dan pelaporan harus ada audit internal dalam rangka penilaian kerja untuk tujuan mengevaluasi dan mengendalaikan aktivitas organisasi menurut (Baihaqi, 2016). Menurut Krina (2003) akuntabilitas adalah prinsip yang menjamin bahwa setiap kegiatan penyelenggaraan pemerintahan dapat dipertanggungjawabkan secara terbuka oleh pelaku kepada pihak-pihak yang terkena dampak penerapan kebijakan. Krina menjelaskan indikator-indikator akuntabilitas adalah Akuntabilitas. Institusi PTN harus mampu mempertanggungjawabkan seluruh rangkaian proses penyelenggaraan PTN terhadap seluruh stakeholders, baik internal maupun eksternal, terutama pada masyarakat umum. Pertanggungjawaban ini dapat dilakukan secara rutin dengan jangka waktu tertentu. Misalnya, dalam hal anggaran setiap tahun perlu dilakukan proses audit, baik audit internal maupun audit eksternal yang dilakukan oleh akuntan publik. Hasil audit maupun laporan pertanggungjawaban lain harus dengan mudah dapat diakses oleh seluruh stakeholders. Selain itu, untuk mendukung akuntabilitas ini, prinsip transparansi juga harus diterapkan dengan benar.

Responsibilitas merupakan kemampuan organisasi untuk mengatur sejauhmana pemberian layanan telah berjalan sesuai dengan aturan-aturan yang diberlakukan atau prosedur yang telah di atur. Responsibilitas mengukur tingkat pastisipasi pemberi layanan melaksanakan tugasnya. Responsibilitas adalah ukuran yang menunjukkan sejauh mana proses pemberian pelayanan publik dilakukan sesuai dengan prinsip-prinsip atau ketentuan-ketentuan administrasi dan organisasi yang benar telah ditetapkan menurut (Muslimah, 2016). Responsibilitas bagi Wijatno (2009) mencerminkan kepatuhan terhadap peraturan perundang-undangan serta pelaksanaan tanggung jawab terhadap masyarakat dan lingkungan sehingga dapat terpelihara kesinambungan usaha dalam jangka panjang. Setiap individu yang terlibat dalam pengelolaan universitas harus bertanggung jawab atas tindakannya sesuai dengan job description yang telah ditetapkan.

Efektifitas dan efisiensi, output dari seluruh proses penyelenggaraan atau programprogram yang digariskan harus tepat sasaran (efektif) atau sesuai dengan kebutuhan dan harapan stakeholders. Dimana yang menjadi fokus utama adalah efektif dalam menunjang fungsi-fungsi pendidikan, khususnya dalam hal peningkatan mutu akademik dan riset. 
Lussiana, Titik Mildawati dan Fidiana

Dekonstruksi Konsep Good University Governance Dalam Pelaksanaan Anggaran Perguruan Tinggi

Negeri Badan Hukum

Selain itu, penyelenggaraan PTN juga harus efisien dalam pemanfaatan sumber daya untuk melakukannya. Dalam aspek akuntabilitas, Institusi PTN harus mampu mempertanggungjawabkan seluruh rangkaian proses penyelenggaraan PTN terhadap seluruh stakeholders, baik internal maupun eksternal, terutama pada masyarakat umum. Pertanggungjawaban ini dapat dilakukan secara rutin dengan jangka waktu tertentu. Misalnya, dalam hal anggaran setiap tahun perlu dilakukan proses audit, baik audit internal maupun audit eksternal yang dilakukan oleh akuntan publik. Hasil audit maupun laporan pertanggungjawaban lain harus dengan mudah dapat diakses oleh seluruh stakeholders. Selain itu, untuk mendukung akuntabilitas ini, prinsip transparansi juga harus diterapkan dengan benar.

\section{Konsep Anggaran Sektor Publik}

Anggaran merupakan alat akuntansi yang dapat membantu pimpinan organisasi dalam merencanakan dan mengendalikan operasional organisasi. Anggaran memperlihatkan bagaimana sumber daya yang diharapkan akan diperoleh dan dipakai selama periode waktu tertentu. Dalam organisasi sektor publik, anggaran juga mempunyai pengertian tersendiri. Menurut (Mardiasmo, 2009)anggaran sektor publik merupakan alat perencanaan manajemen untuk mencapai tujuan organisasi. Anggaran sektor publik dibuat untuk merencanakan tindakan apa yang akan dilakukan oleh pemerintah, berapa biaya yang dibutuhkan, dan berapa hasil yang diperoleh dari belanja pemerintah tersebut. (Bastian, 2010) juga menyatakan bahwa anggaran sektor publik adalah Paket pernyataan menyangkut perkiraan penerimaan dan pengeluaran yang diharapkan akan terjadi dalam satu atau beberapa periode mendatang. Namun dari referensi di atas penulis dapat menyimpulkan bahwa anggaran sektor publik adalah suatu rencana yang disusun oleh instansi pemerintah mengenai perkiraan penerimaan dan pengeluaran selama periode tertentu untuk mencapai tujuan tertentu.

Menurut (Mardiasmo, 2009) anggaran sektor publik memiliki beberapa fungsi utama, yaitu Alat Perencanaan (Planning Tool) dimana anggaran di buat untuk mencapai tujuan organisasi. Pemerintah menyusun anggaran untuk merencanakan tindakan yang dilakukan, berapa biaya yang dibutuhkan dan hasil apa yang hendak di capai dari belanja pemerintah tersebut. Sebagai alat perencanaan, anggaran di susun agar kebijakan sesuai dengan visi dan misi pemerintah. Kebijakan anggaran tersebut berupa program dan kegiatan yang sesuai tujuan pemerintah dan dialokasikan pendanaannya beserta indikator kinerja dan target pencapaian strategis yang diharapkan.

Anggaran sebagai Alat Pengendali (Control Tool), dimana anggaran dapat memberikan rencana detail atas pendapatan dan pengeluaran pemerintah sehingga pembelanjaan yang dilakukan dapat dipertanggungjawabkan kepada publik. Sebagai alat pengendali, diharapkan meminimalisir kesalahan alokasi anggaran seperti overspending atau underspending. Anggaran juga alat untuk memonitor kondisi keuangan dan pelaksanaan operasional program atau kegiatan pemerintah. Pengendalian anggaran sektor publik dapat dilakukan dengan cara membandingkan kinerja aktual dan kinerja yang dianggarkan, menghitung selisih anggaran, menemukan penyebab yang dapat dikendalikan dan yang tidak dapat dikendalikan serta merevisi standar biaya atau target anggaran tahun berikutnya. 
Lussiana, Titik Mildawati dan Fidiana

Dekonstruksi Konsep Good University Governance Dalam Pelaksanaan Anggaran Perguruan Tinggi

Negeri Badan Hukum

Anggaran sebagai Alat Kebijakan Fiskal (Fiscal Tool), dimana anggaran digunakan untuk menstabilkan, mendorong, dan memfasilitasi kegiatan ekonomi masyarakat sehingga dapat meningkatkan pertumbuhan ekonomi. Selain itu anggaran juga dinilai sebagai Alat Penilaian Kinerja (Performance Measurement Tool), dimana anggaran merupakan alat yang efektif untuk pengendalian dan penilaian kinerja. Pengertian kinerja adalah prestasi kerja berupa keluaran dari suatu kegiatan atau hasil dari suatu program dengan kuantitas dan kualitas yang terukur.

Anggaran juga dapat menjadi Alat Politik (Political Tool) karena anggaran sektor publik disusun atas kesepakatan legislatif dan eksekutif. Dalam proses mencapai persetujuan anggaran publik diperlukan keahlian politik, negosiasi, koalisi dan pemahaman prosedur manajemen keuangan sektor publik. Anggaran yang telah disahkan merupakan dokumen publik yang harus dijalankan oleh eksekutif dengan sebaik-baiknya. Apabila anggaran tidak dilaksanakan dengan baik maka kredibilitas pemerintah dapat menurun dan instrumen anggaran dapat menjadi alat menekan pemerintahan. Minimal dapat menurunkan kepercayaan masyarakat kepada pemerintah.

Anggaran sebagai Alat Koordinasi dan Komunikasi (Coordination and communication tool), dimana setiap unit kerja pemerintah secara berjenjang terlibat dalam penyusunan anggaran. Oleh karena itu anggaran perlu disusun dengan perencanaan dan koordinasi yang baik dalam suatu sistem terpadu. Hal ini dilakukan agar program dan rencana kerja anggaran dapat dipantau kinerjanya dan terhindar dari duplikasi. Kemudian agar program dan kegiatan yang disusun dalam anggaran dapat dilaksanakan dengan baik maka perlu dikomunikasikan ke seluruh unit dalam suatu organisasi.

Anggaran dikatakan sebagai Alat motivasi (Motivation tool) karena anggaran disusun dengan target yang terukur dan dapat dilaksanakan. Dalam perencanaan terdapat target dan tujuan yang ingin dicapai dan diharapkan dapat terlaksana dengan baik. Oleh karena itu target yang hendak dicapai hendaknya tidak terlalu tinggi (ambisius) namun juga tidak terlalu mudah untuk dilaksanakan. Informasi (input) yang diperoleh dari evaluasi kinerja anggaran juga dapat menjadi dasar pemberian insentif (stick and carrot) bagi pekerja. Dan yang terakhir anggaran juga dapat menjadi Alat menciptakan ruang publik (Public Sphere) dimana seluruh komponen masyarakat dapat terlibat dalam penyusunan anggaran sektor publik. Masyarakat umum, LSM, asosiasi dan akademisi dapat menyampaikan aspirasinya. Hal ini penting karena dalam pelaksanaannya anggaran berdampak langsung pada aktivitas sosial ekonomi masyarakat. Tugas pemangku kepentingan dan pemerintah untuk memenuhi kebutuhan masyarakat ini dengan skala prioritas sesuai visi misi pemerintahan. Dengan terpenuhinya aspirasi mereka maka kondisi bernegara dapat lebih baik dan terhindar dari demo dan kegaduhan politik yang menguras energi bangsa.

\section{Konsep Kinerja Organisasi}

Penilaian kinerja organisasi harus dilakukan dengan prinsip-prinsip yang baik dan benar. Menurut Mahsun, (2006:26) terdapat empat elemen pengukuran kinerja organisasi yang pertama yaitu menetapkan tujuan, sasaran dan strategi organisasi, kemudian merumuskan indikator dan ukuran kinerja, serta mengukur tingkat ketercapaian tujuan dan sasaran-sasaran organisasi, dan terkahir evaluasi kinerja (umpan balik, penilaian 
Lussiana, Titik Mildawati dan Fidiana

Dekonstruksi Konsep Good University Governance Dalam Pelaksanaan Anggaran Perguruan Tinggi

Negeri Badan Hukum

kemajuan organisasi meningkatkan kualitas pengambilan keputusan dan akuntabilitas). Pengukuran kinerja bukan tujuan akhir melainkan merupakan alat agar dihasilkan manajemen yang lebih efisien dan terjadi peningkatan kinerja. Hasil dari pengukuran kinerja akan memberi tahu kita apa yang telah terjadi bukan mengapa hal itu terjadi atau apa yang harus mengapa hal itu terjadi atau apa yang harus dilakukan.

Pengukuran kinerja merupakan bagian penting dari proses pengendalian manajemen, baik organisasi publik maupun swasta. Namun karena sifat dan karakteristik organisasi sektor publik berbeda dengan sektor swasta, penekanan dan orientasi pengukuran kinerjanya pun terdapat perbedaan. Menurut (Mahmudi, 2015), tujuan dilakukan penilaian kinerja di sektor publik ada 6 (enam) diantaranya adalah mengetahui tingkat ketercapaian tujuan organisasi, menyediakan sarana pembelajaran pegawai, memperbaiki kinerja periode berikutnya memberikan pertimbangan yang sistematik dalam pembuatan keputusan, pemberian reward dan punishment, memotivasi pegawai, dan menciptakan akuntabilitas publik. Kesimpulannya adalah pengukuran kinerja merupakan suatu cara untuk mengetahui atau menilai sejauh mana tujuan, sasaran dan program dari suatu organisasi bisa tercapai. Pengukuran kinerja juga dapat digunakan sebagai bahan pertimbangan dalam membuat keputusan untuk perbaikan kinerja dimasa mendatang.

Menurut (Mahmudi, 2015) , informasi mengenai kinerja sangat penting dalam rangka menciptakan good governance. Manajemen yang baik dan akuntabel membutuhkan indikator kinerja untuk mengukur sukses atau tidaknya organisasi. Informasi kinerja tersebut diorientasikan sebagai pedoman bukan sebagai alat pengendalian. Pemanfaatan indikator kinerja sangat penting untuk mengetahui apakah suatu organisasi, aktivitas atau program telah memenuhi prinsip ekonomi, efisien dan efektif. Indikator untuk tiap-tiap unit organisasi berbeda-beda tergantung pada tipe pelayanan yang dihasilkan. Selanjutnya indikator kinerja merupakan sarana atau alat (means) untuk mengukur hasil suatu aktivitas, kegiatan, atau proses dan bukan hasil atau tujuan itu sendiri (ends).

Peran indikator kinerja bagi organisasi sektor publik adalah memberikan tanda atau rambu-rambu bagi manajer atau pihakluar untuk menilai kinerja organisasi. Indikator kinerja akan bermanfaat apabila digunakan untuk mengukur sesuatu. Dengan demikian peran utama indikator kinerja adalah sebagai alat untuk mengukur kinerja. Indikator kinerja juga berperan sebagai pembanding terbaik. Hal ini berarti bahwa untuk meniru organisasi terbaik, maka perlu digunakan standar kinerja organisasi terbaik tersebut. Standar kinerja terbaik memuat indikator-indikator kinerja dengan nilai tertentu.Indikator kinerja dapat dimanfaatkan baik oleh pihak internal organisasi maupun pihak luar. Bagi pihak internal, indikator kinerja digunakan untuk melaporkan hasil kerja. Hal itu terkait dengan tujuan pemenuhan akuntabilitas manajerial.

Indikator kinerja bagi manajemen dapat digunakan sebagai sarana melakukan perbaikan berkelanjutan (continuous improvement). Bagi pihak internal indikator kinerja digunakan untuk melakukan evaluasi dan pemantauan kinerja. Secara umum, indikator kinerja memiliki beberapa peran diantaranya adalah membantu memperbaiki praktik manajemen, meningkatkan akuntabilitas manajemen dengan memberikan tanggung jawab secara eksplisit dan pemberian bukti atas suatu keberhasilan atau kegagalan, 
Lussiana, Titik Mildawati dan Fidiana

Dekonstruksi Konsep Good University Governance Dalam Pelaksanaan Anggaran Perguruan Tinggi

Negeri Badan Hukum

memberikan dasar untuk melakukan perencanaan kebijakan dan pengendalian, memberikan informasi yang esensial kepada manajemen sehingga memungkinkan bagi manajemen untuk melakukan pengendalian kinerja disemua level organisasi, memberikan dasar untuk pemberian kompensasi kepada staf.

\section{PENUTUP}

Kinerja suatu organisasi dinilai baik jika organisasi yang bersangkutan mampu melaksankan tugas - tugas dalam rangka mencapai visi, misi dan tujuan yang telah ditetapkan pada standar yang tinggi dengan biaya yang rendah. Secara teknis kinerja yang baik bagi suatu organisasi dapat tercapai ketika perencanaan dan anggaran yang dilakukan oleh organisasi yang bersangkutan dapat mengimplementasikan Good University Governance melalui tercapaianya akuntabilitas, transparansi, responsibilitas, efisien, dan efektif. Transparansi di bidang pengelolaan berarti adanya keterbukaan dalam mengelola suatu kegiatan. Keterbukaan dalam sumber pemasukan dan jumlahnya, rincian penggunaan, dan pertanggung jawabannya harus jelas sehingga bisa memudahkan pihakpihak yang berkepentingan untuk mengetahuinya.

Transparansi keuangan diperlukan dalam rangka meningkatkan tingkat kepercayaan stakeholder, diantaranya orangtua mahasiswa, masyarakat dan pemerintah. Disamping itu transparansi dapat menciptakan kepercayaan timbal balik antara pemerintah, masyarakat, orang tua mahasiswa dan seluruh civitas academica melalui penyediaan informasi dan menjamin kemudahan di dalam memperoleh informasi yang akurat dan memadai.

Akuntabilitas dapat meningkatkan kinerja organisasi karena merupakan suatu bentuk kewajiban dalam mempertanggungjawabkan keberhasilan atau kegagalan pelaksanaan perencanaan organisasi dalam mencapai tujuan dan sasaran yang telah di tetapkan sebelumnya, melalui suatu media pertanggungjawaban yang dilaksanakan secara periodik. Selain itu akuntabilitas juga merupakan prinsip yang menjamin bahwa setiap kegiatan penyelenggaraan pemerintahan dapat dipertanggungjawabkan secara terbuka oleh pelaku kepada pihak-pihak yang terkena dampak penerapan kebijakan. Responsibilitas menggambarkan apakah pelaksanaan birokrasi dilakukan dengan prinsipprinsip administrasi yang benar dengan kebijakan birokrasi, baik yang eksplisit maupun implisit. Responsibilitas (responsibility) merupakan konsep yang berkenaan dengan standar profesional dan kompetensi teknis yang dimiliki administrator (birokrasi publik) dalam menjalankan tugasnya. Administrasi negara dinilai responsibel apabila pelakunya memiliki standard profesionalisme atau kompetensi teknis yang tinggi.

Efisiensi adalah perbandingan antara output dengan input dimana ukuran efisien dapat dikembangkan dengan menghubungkan antara biaya yang sesungguhnya dengan biaya standar yang telah ditetapkan sebelumnya (misalnya anggaran). Dikatakan efisien jika suatu produk atau hasil kerja dapat dicapai dengan dana yang serendah-rendahnya. Efisien berhubungan erat dengan konsep produktivitas dalam arti berdaya guna dalam penggunaan sumber daya, dimana penggunaan sumber daya diminimalkan dan hasilnya yang dimaksimalkan. Keefektifan organisasi dapat di definisikan sebagai tingkatan pencapaian organisasi atas tujuan jangka pendek dan jangka panjang yang didekati berdasarkan nilai-nilai bersaing dari nilai-nilai organisasinya. 
Dengan tercapainya anggaran yang memenuhi indikator Good University Governance, maka perbaikan pelayanan akan terpenuhi, kecepatan dan ketepatan pengambilan keputusan dapat terlaksana, serta mempersingkat birokrasi yang berbelitbelit. PTN badan hukum dituntut untuk melakukan pengembangan, perbaikan dan pembangunan dengan baik dan cepat baik ditingkat nasional maupun internasional secara mandiri/otonom, sehingga ketercapaian Good University Governance terntunya akan menjadi standar bagi pemerintah untuk menilai kinerja PTN Badan Hukum yang ada di Indonesia. Upaya nyata untuk itu telah dilakukan oleh pemerintah, salah satunya dengan adanya Peraturan Menristek Dikti Nomor 40 Tahun 2016 yang mengatur tentang penyusunan laporan kinerja organisasi bagi PTN Badan Hukum.

Pada kenyataanya yang terjadi saat ini telah ada 11 (sebelas) Perguruan Tinggi Negeri yang telah diubah statusnya menjadi PTN-BH dan peningkatan yang terlihat jelas adalah ranking PTN tersebut di tingkat internasional meningkat. Seluruh PTN Badan Hukum yang ada di Indonesia saling berloba untuk memperbaiki diri dan mecapai prestasi-prestasi luar biasa untuk mempertahankan eksistensi dan pembuktian bahwa kepercayaan pemerintah untuk memberikan kewenangan yang otonom dapat membawa pendidikan Indonesia ketingkat yang lebih baik dimata dunia.

\section{REFERENSI}

Andrianto, N. (2007). Transparasi dan Akuntabilitas Publik Melalui E-Government. Malang: Bayumedia Publisher.

Anggarini, P. (2010). Anggaran Berbasis Kinerja. Yogyakarta: YKPN.

Anwar dan Partolo. (2012). Penerapan Model tata Kelola Keuangan Perguruan Tinggi yang Baik untuk Mewujudkan Good University Governance (studi pada PTM seIndonesia). JAIUMY. Retrieved from www.repositoryumy.com/JAIUMY/pdf/misbah.pdf

Baihaqi. (2016). Analisis Pengukuran Kinerja Perusahaan Menggunakan Pendekatan Balanced Scorecard (Studi Kasus di PT. Monako Tunggal Jakarta. Universitas Islam Indonesia.

Bastian. (2010). Akuntansi Sektor Publik Suatu Penganta (Ketiga). Jakarta: Erlangga. Carnagie, G. D. (2009). The ABC of University Governance. Campus Review, 19, 9.

Considine, D. (2004). University Governance, Corporations And Culture: The Impact of Corporate Law on The Development of Appropriate Regulation, Compliance and Recognition of Diverse University Cultures. Paper Proceedings of the Australian University Quality Forum, Adelaide, 9.

Halim, I. (2012). Anggaran dan Partsisipasi Anggaran. Jakarta: Grafindo.

Hansen dan Mowen. (2004). Manajemen Biaya (Buku Kedua). Jakarta: Salemba Empat.

Harris, J., dan G. C. (2009). The Time are Changing: A Call for Governing Boards of Universities to Awaken to Sarbanes-Oxley and Practices of Good Governance. Decision Line, 40 (5), 21.

Mahmudi. (2015). Manajemen Kinerja Sektor Publik (Kedua). Yogyakarta: YKPN. Mardiasmo. (2009). Akuntansi Sektor Publik. Yogyakarta: ANDI. 


\section{Lussiana, Titik Mildawati dan Fidiana}

Dekonstruksi Konsep Good University Governance Dalam Pelaksanaan Anggaran Perguruan Tinggi Negeri Badan Hukum

Muslimah. (2016). Responsibilitas Pelayanan Publik Kabupaten Maros. Makassar. Rudianto. (2009). Akuntansi Manajemen. Yogyakarta: Grasindo.

Shattock, M. (2006). Managing and Good Governance in Higher Education (Berkshire:). Maidenhead.

Sukirman dan Maylina. (2012). Peran Internal Audit dalam Upaya Mewujudkan Good University Governance di UNNES. Jurnal Dinamika Akuntansi, 4 (1), 64-71.

Wijatno. (2009). Pengantar Entrepreneurship. Jakarta: Gramedia Indonesia. 